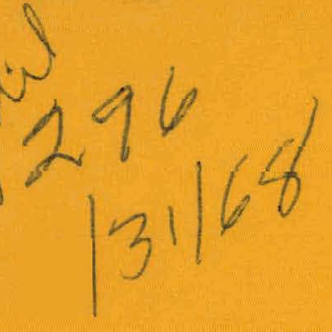

\title{
ADJUSTER
}

IN-1148

\section{A FORCE CONSTANT ADJUSTER PROGRAM TO OBTAIN LEAST SQUARES FIT TO OBSERVED FREQUENCIES OF MOLECULES AND CRYSTALS}

J. K. Boyter and H. L. McMurry

\section{IDAHO NUCLEAR CORPORATION NATIONAL REACTOR TESTING STATION ILAHU FALLS, ILAHU}




\section{DISCLAIMER}

This report was prepared as an account of work sponsored by an agency of the United States Government. Neither the United States Government nor any agency Thereof, nor any of their employees, makes any warranty, express or implied, or assumes any legal liability or responsibility for the accuracy, completeness, or usefulness of any information, apparatus, product, or process disclosed, or represents that its use would not infringe privately owned rights. Reference herein to any specific commercial product, process, or service by trade name, trademark, manufacturer, or otherwise does not necessarily constitute or imply its endorsement, recommendation, or favoring by the United States Government or any agency thereof. The views and opinions of authors expressed herein do not necessarily state or reflect those of the United States Government or any agency thereof. 


\section{DISCLAIMER}

Portions of this document may be illegible in electronic image products. Images are produced from the best available original document. 
Printed in the United States of America Available from

Clcaringhousc for Fedcral Scientific and Technical Information National Bureau of Standards, U. S. Department of Commerce Springfield, Virginia 22151

Price: Printed Copy $\$ 3.00$; Microfiche $\$ 0.65$

\section{LEGAL NOTICE}

This report was prepared as an account of Government sponsored work. Neither the United States, nor the Commission, nor any person acting on behalf of the Commission:

A. Makes any warranty or representation, express or implied, with respect to the accuracy, completeness, or usefulness of the information contained in this report, or that the use of any information, apparatus, method, or process disclosed in this report may not infringe privately owned rights; or

B. Assumes any liabilities with respect to the use of, or for damages resulting from the use of any information, apparatus, method, or process disclosed in this report.

As used in the above, "person acting on behalf of the Commission" includes any employee or contractor of the Commission, or employee of such contractor, to the extent that such employee or contractor of the Commission, or employee of such contractor prepares, disseminates, or provides access to, any information pursuant to his employment or contract with the Commission, or his employment with such contractor. 
IN-1148

Lssued: December $196^{\circ}$

Mathematics and Computers

TID-4500

LEGAL NOTICE

Thls romet wa prepared as an account of Government sponsored work. Neither the United States, nor the Commission, nor any person acting on behalf of the Commission:

A. Makes any warranty or representation, expressed or implied, with respect to the accuracy, completeness, or usefulness of the information contalned in this report, or that the use

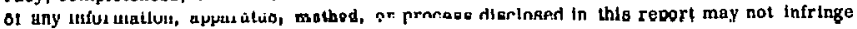
privately owned rights; or

B. Assumes any liablitites with respect to the use of, or for damages resulting from the B. Any information, apparatus, method, or process disclosed in this report.

AB us in the commission" includes any emAa used in the ab the ployee or contractor of the Comal such employee or contractor of the Comm or employee of disseminates, or provdes access $t o$, any informatha pursuant wo big employment or contract with the Commission, or hls employment with such contractor.

ADJUSTER

A FORCE CONSTANT ADJUSTER PROGRAM TO OBTAIN LEAST SQUARES FIT

TO OBSERVED FREQUENCIES OF MOLECULES AND CRYSTALS

by

J. K. Boyter and H. L. McMurry

IDAHO NUCLEAR CORPORATION

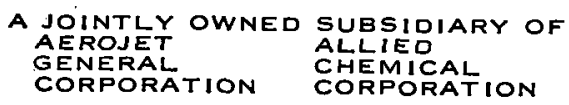

ALLIED

CORPORATION CORPORATION

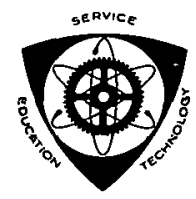

U. S. Atomic Energy Commission Research and Development Report

Issued Under Contract AT(10-1)-1230

Idaho Operations Office 

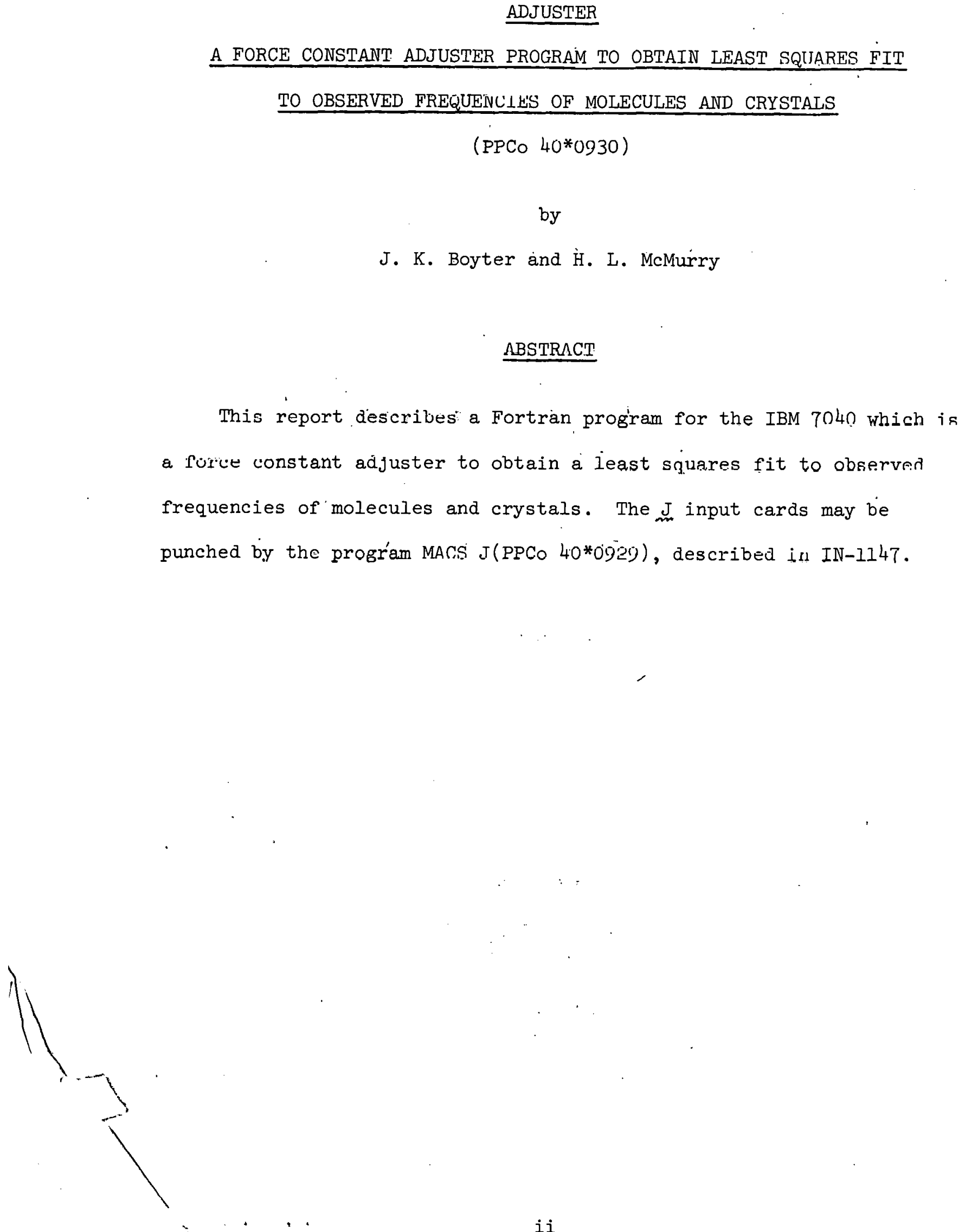
CONTENTS

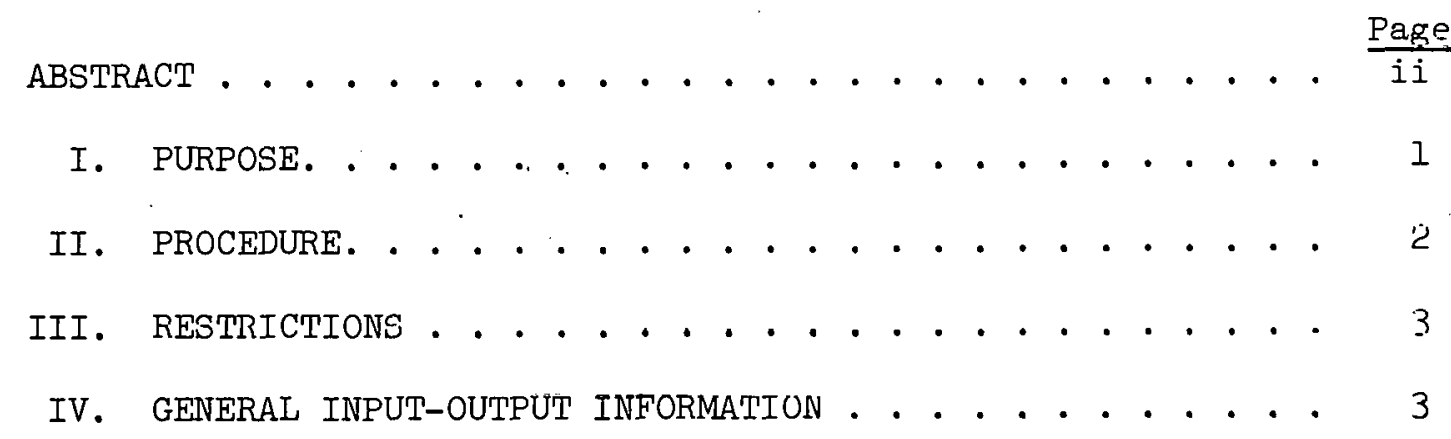


ADJUSTER

A PORCE CONGTANT ADJUSTER PROGRAM TO OBTAIN LEAST SQUARES FIT

TO OBSERVED FREQUENCIES OF MOLECULES AND CRYSTALS

PROGRAM NO. $40 * 0930$

\section{PURPOSE}

Let $\dot{\sim}_{0}$ denote a column matrix the $\mathrm{n}$ elements of which are observed vibration frequencies (or energies) for a molecule or a crystal (or any other system for that matter) where these frequencies can be calculated using a force field defined by $m$ force constants. Let $\underline{\sim}^{(0)}$ be a column matrix the $\mathrm{n}$ elements of which are the calculated vibration frequencie's corresponding to the ones in $\nu_{0^{\circ}}$ This superscript (0) denotes that these are obtained with some initial set of the $m$ force constants.

Let $\underset{\sim}{J}$ denote an $n x$ matrix such that $J_{s t}=-\frac{\Delta v_{s}}{\Delta f_{t}}$. Here $\Delta v_{s}$ denotes the change in the $s$ th calculated frequency when the force constant $f_{t}$ is changed by $\Delta f_{t}$, all other force constants are held fixed. The negative sign has been inserted so that Eq. (1) below appears with a positive sign on the right side.

Let $\underset{\sim}{W}$ denote a diagonal weight factor matrix with $\mathrm{n}$ rows and $\mathrm{n}$ columns such that $w_{t t}=\frac{1}{v^{2}}$ where $v_{\text {ot }}$ is the observed value of the t th element in $\stackrel{\sim}{0}_{0}$.

Let $f_{\sim}^{(0)}$ denote a column matrix of $m$ elements which are the initial set of force constants used to compute the $v^{(0)}$. Let $\underset{\sim}{V}=\underline{\sim}^{(0)}-{\underset{\sim}{0}}_{0}$, a column matrix with $\mathrm{n}$ elements. Then, following D. E. Mann, T. Shimanouchi, J. H. Meal and L. Fano (J. Chem. Phys. 27, 43 (1957)), it can be shown that the force constants must be altered according to the following equation if the sum of the squared 
deviations between calculated and observed frequencies is to be minimized

$$
\left.\Delta \underline{\sim}=\left[\tilde{\sim}^{\prime} \underset{\sim}{\mathrm{W}}\right]^{-1}\right]^{-1} \underset{\sim}{\mathrm{W}} \underset{\sim}{\mathrm{V}}
$$

In ( 1$), \Delta \underset{\sim}{f}$ is a column matrix of $\mathrm{m}$.elements which are the predicted changes in the force constiants such that n. now set $f_{\sim}^{(I)}$ Elven by

$$
{\underset{\sim}{f}}^{(I)}={\underset{\sim}{f}}^{(0)}+\Delta f
$$

will lead toward new calculated frequencies $\underline{\sim}^{(1)}$ which yield a minimum sum of squared deviations between observed and calculated frequencies (weighted, however, by $W$ ). Thus, the minimized sum is

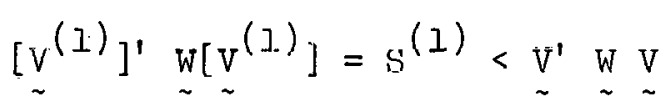

where

$$
\begin{aligned}
& \underline{v}^{(I)}={\underset{\sim}{v}}^{(I)}-\underline{\sim}_{0} \\
& \underline{v}=\underline{v}^{\left(0^{\prime}\right)}-\sim_{\sim}^{\nu} \cdot
\end{aligned}
$$

\section{PROCEDURE}

The prograili l.rkes the three matrices:

$$
\begin{aligned}
& \mathrm{J} \text {, the } \mathrm{n} \times \mathrm{m} \text { matrix, } \mathrm{n} \geq \mathrm{m} . \\
& \mathrm{W} \text {, the diagonal } \mathrm{n} \times \mathrm{n} \text { matrix, } \\
& \sim \text {, the } \mathrm{n} \times 1 \text { column vector. }
\end{aligned}
$$

With these matrices, the following $\mathrm{m} x \mathrm{l}$ vector is calculated:

\footnotetext{
* Mann et al. should give this equation with a negative sign in front because their $J$ is the negative of that used here. They have a sign error in their published work.
} 


$$
\left(\mathcal{\sim}^{\prime} \underset{\sim}{\mathrm{W}} \underset{\sim}{J}\right)^{-1} \underset{\sim}{J^{\prime}} \underset{\sim}{\underset{\sim}{W}} \underset{\sim}{\mathbb{V}}=\Delta \underset{\sim}{f}
$$

In calculating $\Delta \underset{\sim}{f}$ the matrix $\left(J^{\prime} \underset{\sim}{W} J\right)$ and its inverse are multiplied together so the precision of the inversion may be observed.

A $\mathrm{n} \times 1$ vector is calculated from $\underset{\sim}{J}$ and $\underset{\sim}{\mathrm{f}:}$

$$
\Delta \underline{\sim}=-\underset{\sim}{J} \underset{\sim}{\sim}
$$

Eq. (2) gives the predicted value for $v^{(1)}-v^{(0)}$ and indicates what may be expected from a full calculation of $v^{(\tilde{I})}$. Usually, the $\Delta \underset{\sim}{v}$ calculated from (2) will not be the same as $\underline{v}^{(1)}-\underline{v}^{(0)}$ calculated from the program because the frequencies are not really linear functions of the force constants as (2) implies. In certain nontrivial cases, (2) is exact. This point is discussed in more detail by J. K. Boyter and A. W. Solbrig, Jr., in IN-1147 (in preparation).

The program also calculates a predicted

$$
\begin{aligned}
\underline{v}^{(I)}-\underline{\sim}_{0} & =\underline{\sim}^{(I)} \\
& =\underset{\sim}{\mathrm{V}}-\underset{\sim}{\mathrm{J} \Delta \underset{\sim}{f}} .
\end{aligned}
$$

III. RESTRICTIONS

The program is dimensioned to take 32 x 32 matrices.

IV. GENERAL INPUT-OUTPUT INFORMATION

Summary of output:

1. The input is printed out and identified.

2. $V^{\prime} \underset{\sim}{W}$, the initial sum of squares.

3. The determinant of $\left[\underset{\sim}{J}{ }_{\sim}^{\prime} \underset{\sim}{J}\right]$.

4. $\left[\sim^{\prime} \underset{\sim}{W}\right]^{-1}\left[\sim^{\prime}{\underset{\sim}{W}}_{\sim}^{J}\right]$, a check on the computations. 
5. $\Delta \underset{\sim}{f}$.

6. $\Delta \underset{\sim}{\nu}=-\underset{\sim}{\mathrm{J}} \underset{\sim}{\mathrm{f}}$.

7. $\underline{\sim}^{(I)}=\underset{\sim}{V}+\Delta \underset{\sim}{v}=\underline{\sim}-\underset{\sim}{\mathrm{T}} \Delta \underset{\sim}{\mathrm{f}}$.

8. $\left[{\underset{\sim}{V}}^{(I)}\right] \cdot \underset{\sim}{\mathrm{W}} \underset{\sim}{\mathrm{V}}(\mathrm{I})$, the final sum of squares.

The input format is as follows:

Type Collumn Format Mnemonice

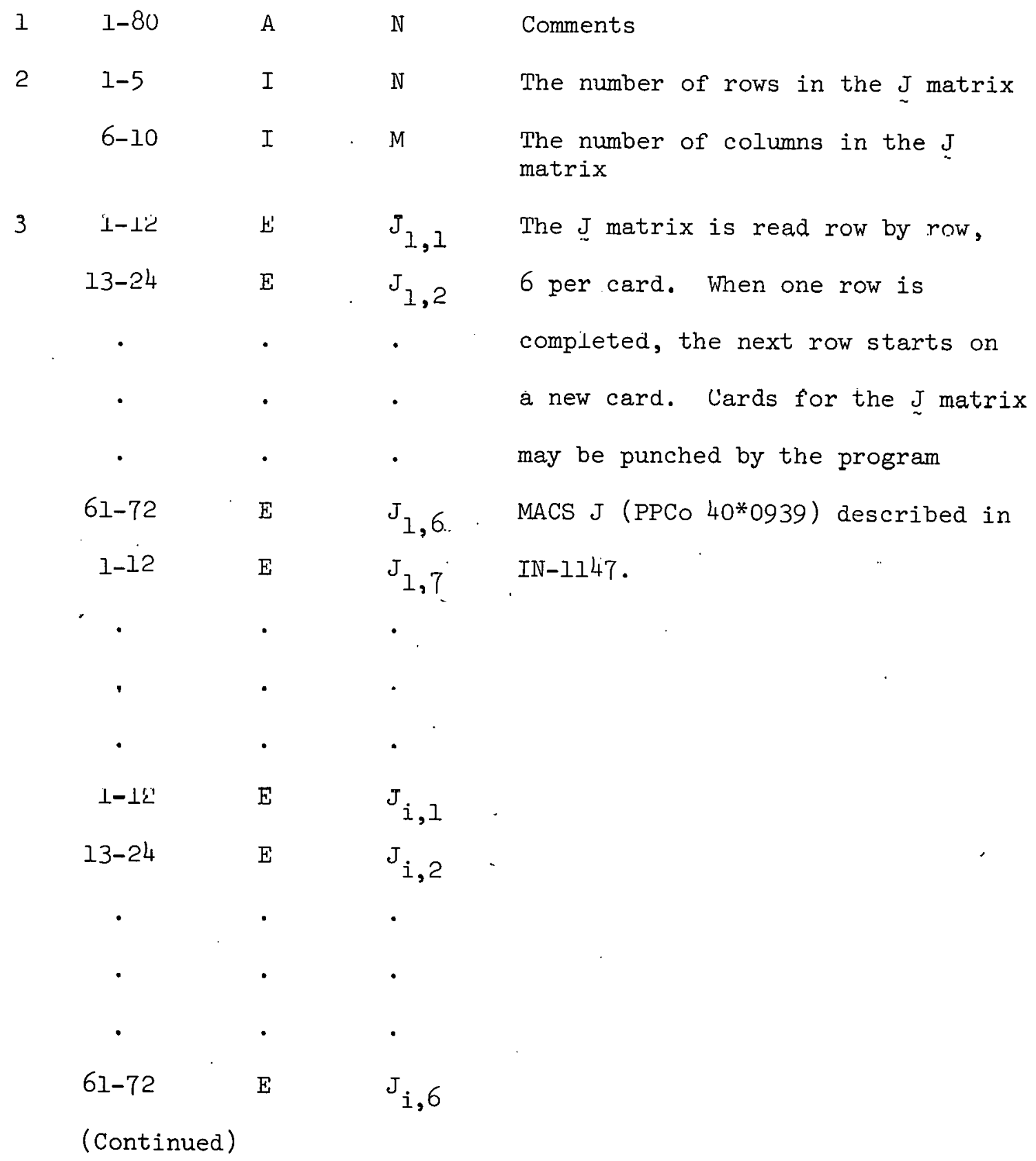

Deseriptiun 
Type Column Format Mnemonics

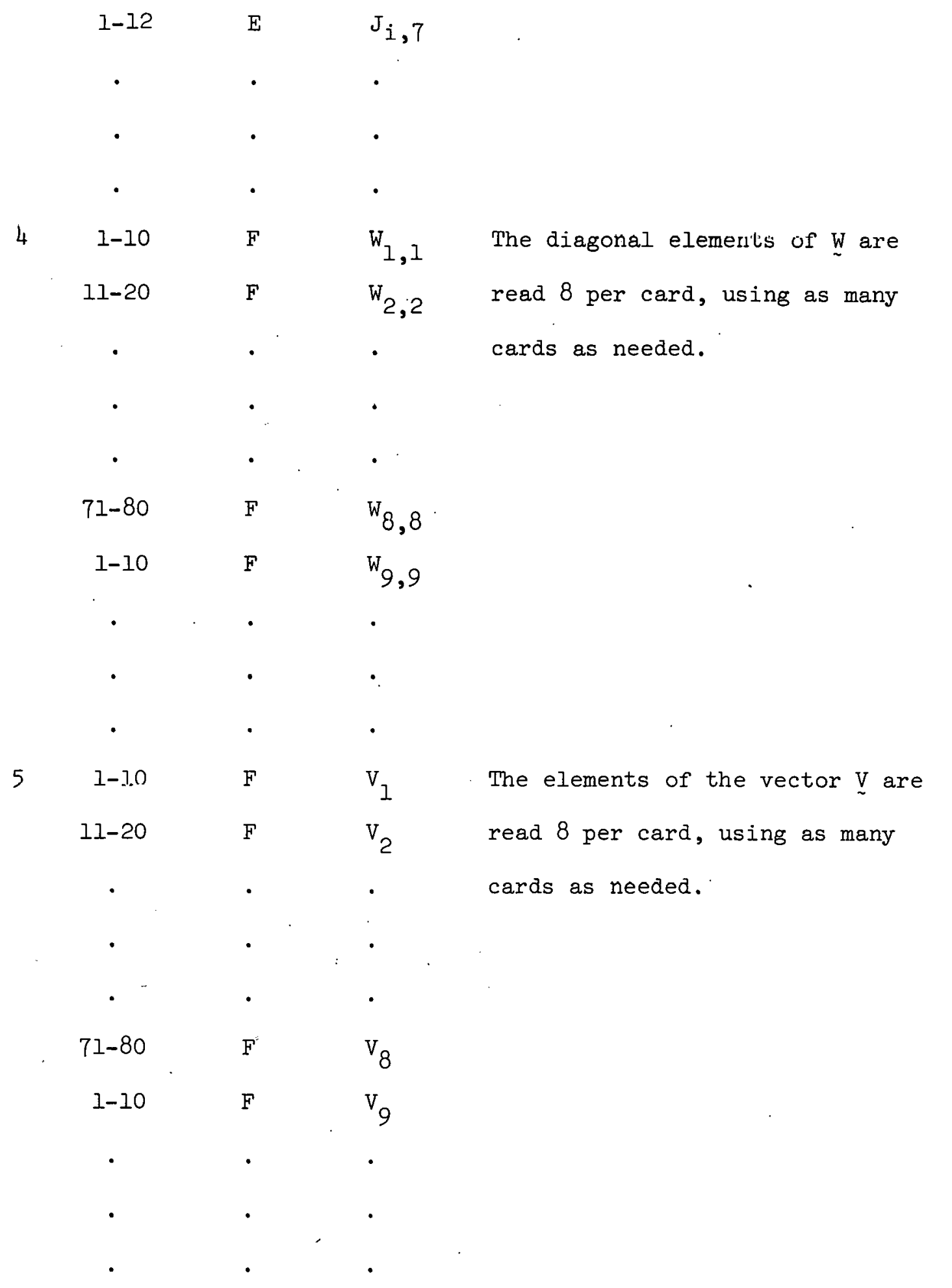

If the user desires a test example, see the Appendix to IN-1077 
the input $\underset{\sim}{ }$ matrix is adapted to the present program, this test example will provide a check on the functioning of most of the present program. 